\title{
KOLLÉGIUMI RENDEZVÉNYSZERVEZÉS BIZTONSÁGTUDOMÁNYI KÉRDÉSEI
}

\section{SECURITY ISSUES OF ORGANIZING EVENTS IN STUDENT HOSTELS}

\author{
Novák János \\ Óbudai Egyetem, Kollégium, Keleti Károly Gazdasági Kar Vállalkozásmenedzsment \\ Intézet, Biztonságtudományi Doktori Iskola. Cím: 1084, Magyarország, Budapest, \\ Tavaszmezö utca,7-13; Telefon: +36-1-6665282,novak.janos@koll.uni-obuda.hu
}

\begin{abstract}
When we hear the term "university hostel", what is the first thing that we think of? Probably for all the fun, overnight parties, great conversations and community life. If we think about it, this is precisely the secondary function of a higher education institution: building a community and social capital given the fact that old student groups, where more or less the same people sat together on classes for 45 years, an experience that has a lasting effect for the rest of our lives, are not present anymore. Many don't see into the organization and realization of these programs. Preliminary background work is an essential element of event organization, and it indeed must cover a great deal of details. During the planning there are many chances of errors that can negatively influence the sense of security of the people present. If we hear news in the media about some tragedy having happened at a venue, we try to avoid that place by all means.
\end{abstract}

Keywords: attention, solution, method, education, communication

\section{Összefoglalás}

Amikor azt halljuk, hogy „egyetemi kollégium” vajon mire is gondolunk elöször? Nagy valószínűséggel a szórakozásra, az éjszakákig tartó bulikra, nagy beszélgetésekre, közösségi életre. Ha jobban belegondolunk ez a másodlagos funkciója egy felsőoktatási kollégiumnak, a közösség építése és a kapcsolati tőke kialakítása - hiszen tudjuk, hogy a jelenlegi felsőoktatási rendszerben nincsenek jelen a régi csoportok, vagy más néven tankörök, ahol annak idején négy-öt éven keresztül túlnyomórészt ugyanazon hallgatók ültek együtt a tanórákon -, ami valljuk be őszintén, meghatározó lesz egész életünk során. Sokan nem látnak bele ezeknek a programoknak a szervezésébe és a lebonyolításába. Az előzetes háttérmunka elengedhetetlen momentuma a rendezvényszervezésnek és nagyon fontos részletekre kell kiterjedjenek. Igen sok hibalehetőséget találunk a szervezések során, amelyek a résztvevők biztonságtudati érzését nagyban befolyásolhatják, sajnos negatív irányba. Ha meghallunk egy hírt a médiában, hogy valamelyik szórakozóhelyen tragédia történt, azt biztosan elkerüljük.

Kulcsszavak: figyelem, megoldás, módszer, nevelés, kommunikáció

\section{Bevezetés - avagy, miért is szük- séges egy kollégiumi rendezvény}

Ha voltunk már felsőoktatási intézményben, egy egyetemi rendezvényen akkor rögtön választ is kapunk a kérdésünkre.
A mai rohanó világ sajátosságai sajnos megmutatkoznak az oktatásban is. Most nem biztos, hogy szeretnénk az oktatási rendszer negatívumairól hallani, de az átalakult felsőoktatás sajnos kikényszeríti ezt. Ahogy az összefoglalóban említésre került, 
a mai felsőoktatási rendszer nem megfelelő a közösségi élet kialakítására, s éppen ezért fontos szerepet tölt be a kollégium intézménye. Teljesen személytelenné alakult át az oktatás, és ennek a hozadéka lett, hogy az emberi kapcsolatok felületessé váltak, amelyet a virtuális világ térhódítása tovább mélyített. Elengedhetetlen a mai növendékek számára a társas lét, vezetőként látjuk, hogy ez szükséges a hallgatóink számára. Éppen ezért véleményünk szerint egy kollégium, a nevelési funkciók mellett komoly szociális funkciókkal is bír. A pihenés mellett szükséges a hallgatók számára a szórakozás is, hiszen ezeken a rendezvényeken, versenyeken, bulikon oldhatják a hétköznapok és a tanulmányok során kialakult feszültséget, kiengedhetik a gőzt és nem utolsó sorban lehetőségük nyílik az ismerkedésre is. Azt is tudjuk, hogy a mai generációnak komoly feladat bármilyen rendezvényt is megszervezni, hiszen igen komoly falba ütközhetünk, ez a fal nem más, mint az érdektelenség. Rengetegen vannak úgy, hogy beburkolóznak a kis szobájukba (főleg ha az egy összkomfortos lakóegység - amire egyre nagyobb az igény a hallgatói körökben) és onnan szinte lehetetlen kizökkenteni őket. Tehát a hallgatói közösségek tagjainak egyre nehezebb az a feladat, hogy társaikat közösségi életre bírják. Ezeket a feladatokat segítik elő a kollégiumi rendezvények, amelyek sokszínüsége felkelthetik az egyes hallgatók érdeklődését. Most ne csak a szórakozásra gondoljunk, hanem például a hallgatói körökre, a klubbokra, a tudományos mühelyekre, szakkollégiumokra, ahol lehetőség nyílik a tudományok más szintű elsajátítására. Természetesen a szabadidős tevékenységek iránt nagyobb az érdeklődés. Egy-egy kirándulás, esti szórakoztató rendezvények képesek nagyobb tömeget megmozgatni. Újabb és újabb megmozdulásokkal egyre érdekesebbé tehetőek a rendezvények. Feladatunknak tartjuk, hogy a hallgató szociális ellátása mellett - értjük ez alatt a szállás szolgáltatást és az ezzel járó biz- tonságos lét tudatát - a mentális életének előrehaladásában is segítséget nyújtsunk. Bizton valljuk, hogy a szervezett programok ezt pozitív irányba tolják, hiszen a visszajelzések ezt mutatják, s ezek számunkra megerősítő tényezők.

\section{Legfontosabb tényező - min- denki biztonsága}

Nem szükséges messzire menjünk, elég, ha bekapcsoljuk valamelyik televíziós csatornát, vagy csak pusztán elolvassuk az írott sajtót. Biztosan tudomásunkra jut egy olyan, nemrég megtörtént negatív esemény a környezetünkben, ami befolyásolhatja a biztonságunkat és a biztonságérzetünket. Mindenképpen különbséget kell tennünk a biztonság és a biztonság tudat között. Természetesen a kettő nagyon sokszor együtt jelenik meg, de mégis megvan mindkettőnek a sajátossága. A biztonság egy nehezen meghatározható fogalom. A mi esetünkben az egyéni biztonságról beszélhetünk, ami az egyén azon képessége, hogy a különböző káros behatásoktól megvédje magát, egyszerübben a fizikai létezésének a biztosítása. A biztonság tudat egy pszichológiai tényező, amely az érzetet mutatja meg számunkra. A biztonságtudatos nevelés nagymértékben meghatározza ezt a kialakult érzetet, amelynek a fokozása szükséges ahhoz, hogy egy megszervezett rendezvényen is hasonló értékeket mutasson, mint pl. egy átlagos otthon töltött napon. Ehhez szükségesek olyan eszközök, amelyek láthatóak a hallgatók számára (pl egy biztonsági szolgálat jelenléte egy megnyugtató tudatosságot jelent számunkra), hiszen amit a szemével felfog az ember, az egy rögzített tudatos - vagy akár tudatalatti - biztonságérzetet nyújthat. Mindemellett elengedhetetlen a megfelelő szintü kommunikáció, amelynek tartalmaznia kell az összes olyan információt, ami szükséges egy esetleges krízishelyzet normák közötti megoldásához. A nemrég történt tragikus események saj- 
nos megnehezítik a dolgunkat, hiszen az egyetemisták, akiknek szervezzük a programokat még a szülőktől nem függetlenek és a szülői aggodalom komoly befolyásoló tényező lehet a részvétel irányába - főleg ha külső helyszínre van szervezve az esemény. Azt ugye tudjuk, hogy soha sincs két egyforma rendezvény még a kollégium berkein belül sem. Mindegyiknek megvannak a sajátosságai. Egyik legfontosabb tényező a résztvevők száma, ugyanis nem mindegy, hogy egy születésnapi zsúron veszünk részt, ahol maximálisan 15-en vesznek részt, vagy egy nagyszabású „Félévnyitó party” az, amire elmegyünk, ahol akár több ezer ember is megfordulhat. Egy vizsgálatot végeztünk, közel száz hallgatónak tettük fel az igen egyszerü kérdést: „Mennyire fontos számodra egy rendezvényen a biztonság érzete?"

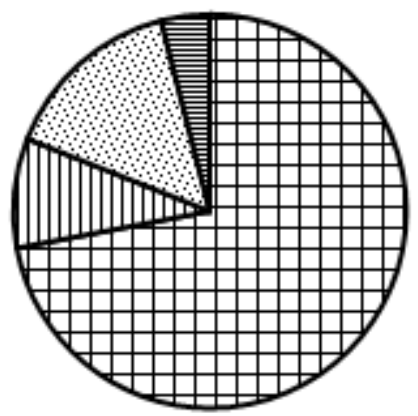

1. ábra. A biztonságtudat fontossága, egyetemi (kollégiumi) rendezvényen

Az eredmény a következő: 72\% számára nagyon fontos; 9\% válaszolta azt, hogy fontos számára; $15 \%$-uk tartja közepesen fontosnak, mindösszesen 4\% tartotta kevésbé fontosnak, és az egyáltalán nem fontos lehetőséget egy hallgató sem választotta. Ahogy várható volt a választ adók nagy számban fontosnak érzik a biztonságérzetet egy rendezvény (buli) során. Valószínűnek tartjuk, hogy ez a későbbiekben még magasabb arányokat fog mutatni.

\section{A szervezői csoport kiválasztá- sának tényezői és ennek hatásai}

Ha rendezvényszervezésről beszélünk, akkor szinte lehetetlen egymagunknak dolgozni. Minden esetben szükség van egy szervező bizottságra, amit inkább nevezzünk szervező csapatnak. Ennek a kiválasztása igen komoly előkészületeket igényel. Ha megpróbáljuk megfogalmazni a rendezvényszervezés fogalmát az valahogy így szólna.

A rendezvényszervezés elöre meghatározott célból, adott helyen és időben tartott összejövetelekkel kapcsolatos teljes körü előkészítő, szervező, összehangoló munka, amely magába foglalja az esemény megvalósításával kapcsolatos infrastruktúra biztosítását, valamint a részvevőkről való gondoskodást. A témánkat tekintve a mondat végén van a hangsúly. A személyzet egyik feladata, hogy a rendkívüli eseményeket megelőzze, illetve annak bekövetkezése esetén annak megfelelő kezelése. Azt meg sem kell említenünk, hogy erre nem mindenki képes. Ezt meg lehet tanulni, de mindenképp jobb, ha valakinek alapból rendelkezik az ehhez szükséges kompetenciákkal. Ha valaki mondjuk, nagyméretü egyén nem lehetünk biztosak abban, hogy biztonságban fogjuk érezni magunkat mellette. A csapat nem megfelelő kiválasztása sok problémát hozhat a szervezési folyamatok alatt nem beszélve a lebonyolítás időszakáról. Sok módszert találhatunk a kiválasztásra, lényeges és fontos tényező, hogy a csapattagok gondolkodásmódja megfeleljen az elvárásoknak. Ha belegondolnunk az egyik elsődleges feladat a csapaton belüli félelem eloszlatása. Ez egyértelmüek vezetői feladat. Végeredményben a csoport kiválasztásával bizonyos biztonságtudati tényezők eloszlathatóak. Ha a „személyes respect” megvan és ez mellett az illető kompetenciái is megvannak (kreativitás, tudás, intelligencia, kommunikációs készségek, szociális felelősségtudat, konfliktuskezelés stb.) az képes 
lehet bizonyos félelmi érzetek csökkentésére esetleg megszüntetésére.

\section{Akin sok minden múlik - a veze- tó és módszerei}

A rendezvényszervezésnek egyik legérdekesebb, de egyben a leghálátlanabb feladatainak egyike a vezetés. Ha belegondolunk, mennyi dolga is van egy föszervezőnek, vagy vezetőnek, akkor nyugodtan szorozzuk meg a gondolatainkat kettővel. Ha a biztonságtudati tényezőket vizsgáljuk, amit a szervezői szinten megemlítettünk, a vezetők esetében megnövekszik. Egy vezető akár a puszta megjelenésével is képes egy egyfajta pszichikai védettséget sugározni. Ha egyes vezetői stílusok (Lewin-féle megközelítési mód) attitüdjeit megfigyeljük, megtudhatjuk, hogy mind az autokrata mind pedig a demokrata vezetöi stílust követő emberek számára is fontos a biztonságérzet és ennél fogva fontos számára az is, hogy a körülötte dolgozó csoporttagok, illetve a résztvevők számára is ezt éreztesse. Ha kimagasló eredményeket szeretnénk elérni, akkor kivételes (kiváló) tehetségü és megbízható emberekre van szükségünk, akik remek attitüdökkel vannak felvértezve.

Lewin arra a megállapításra jutott, hogy: - a leghatékonyabb az autokratikus vezetésủ stílust elfogadó csoport, illetve vezetési stílus volt;

- a legnagyobb élményt adó, s így a legnépszerübb a demokratikus vezetés volt;

- a legeredménytelenebbnek a szabad kezet adó vezetési stílus bizonyult.

Habár sokan a demokratikus vezetési módot látják a leghatékonyabb elvnek, véleményünk szerint nincsen helyes és helytelen vezetési stílus a gyakorlati életben. Egyrészt azért, mert külön-külön, ilyen tisztán senki sem tudja megvalósítani őket. Van, akire az egyes stílusjellemzők (például autokratikus: nem kompromisszum kész, önkényes vezetés) gyakoriabbak, mégis elöfordul, hogy egy másik stílus eszközeivel (mondjuk lazább baráti megnyilvánulásokkal) próbálja hatékonyabb munkára ösztönözni a dolgozókat. Másrészt pedig a vezetőknek a szituációkhoz, emberekhez kell igazodniuk, mivel minden személyiségre más beállítódás van hatással. Egy rugalmas irányítási mód megalkotására kell törekedni, ahol a vezetési stílusok ,keverednek” (nem zárják ki egymást), és iránytüként utat mutatnak a hallgatók viselkedésének megfejtésében.

\section{5. Összegzés}

Eme néhány példán keresztül reméljük sikerült betekintést nyújtani az egyetemi (kollégiumi) rendezvények szervezésének összetetségére. Mindenki azon fáradozik, hogy a hallgatók (a résztvevők) kulturált kereteken belül érezzék jól magukat. A biztonságtudat érzete a mai világban igen központi fontosságúvá vált. Befolyásolhatja ezt a környezet, a kultúra, a személyiségek és még sorolhatnánk. Számunkra lényeges ennek fenntartása és természetesen fokozatosan a jobbá tétele a már ismert és a jövőbeni módszerek rendszeres segítségével és alkalmazásával. Attitüdjeink, ha nehezen is, de képesek változni.

\section{Szakirodalmi hivatkozások}

[1]. Pataki Ferenc: Csoportlélektan, Gondolat kiadó, Budapest, 1980.

[2]. Beblin Meredith: A team, avagy az együttmüködő csoport, SHL Hungary Budapest, 1999.

[3]. Vas Judit, Herskó Anna: Módszerek c. film (Lewin kutatásai), 1968.

[4]. Novák János: A rendezvényszervezés buktatói (szakdolgozat), SZTE-JGYPK, 2006.

[5]. Rozgonyi Tiborné: Személypercepció és attitüd (A társas világ kognitív és érzelmi vonatkozásai), Jegyzet és szemelvénygyüjtemény II. 2001. 